This is a so-called personal version (author's manuscript as accepted for publishing after the review process but prior to final layout and copyediting) of the article:

Schildt, Henri, Mantere, Saku \& Vaara, Eero. 2011. Reasonability and the Linguistic Division of Labor in Institutional Work. Journal of Management Inquiry. 20 (1), 82-86.

Researchers are kindly asked to use the official publication in references.

\title{
Reasonability and the Linguistic Division of Labor in Institutional Work
}

\author{
Henri Schildt
}

Hanken School of Economics

Saku Mantere

Hanken School of Economics

\section{Eero Vaara}

EM Lyon

Hanken School of Economics 


\begin{abstract}
We examine institutional work from a discursive perspective and argue that reasonability, the existence of acceptable justifying reasons for beliefs and practices, is a key part of legitimation. Drawing on philosophy of language, we maintain that institutional work takes place in the context of 'space of reasons' determined by widely held assumptions about what is reasonable and what is not. We argue that reasonability provides the main contextual constraint of institutional work, its major outcome, and a key trigger for actors to engage in it. We draw on Hilary Putnam's concept 'division of linguistic labor' to highlight the specialized distribution of knowledge and authority in defining valid ways of reasoning. In this view, individuals use institutionalized vocabularies to reason about their choices and understand their context with limited understanding of how and why these structures have become what they are. We highlight the need to understand how professions and other actors establish and maintain the criteria of reasoning in various areas of expertise through discursive institutional work.
\end{abstract}

Keywords: institutions, reasoning, discourse, institutional work, institutional logics

"[T]here are two sorts of tools in the world: there are tools like a hammer or a screwdriver which can be used by one person; and there are tools like a steamship which require the cooperative activity of a number of persons to use. Words have been thought of too much on the model of the first sort of tool."

Hilary Putnam, 1975, p. 229

To become and remain legitimate, institutionalized practices need reasons for their existence. The production and maintenance of such justifications can be seen as a central part of institutional work. Studies on institutional entrepreneurship (Hardy \& Maguire, 2008) have examined the role of social actors in changing institutions, and recent analyses of institutional work extend the reach of institutional theory to actors' efforts at sustaining and disrupting institutions (Lawrence, Suddaby, \& Leca, 2009). Cognitive underpinnings of institutions are to a large extent constituted through language, and attempts to create, maintain, or disrupt cognitions typically involve discourse in terms of rhetoric, narratives, and texts (Phillips, Lawrence, \& Hardy, 2004). In particular, rhetorical (Suddaby \& Greenwood, 2005) and discursive (Vaara \& Tienari, 2008) legitimation play a key role in such discursive institutional work. Yet, we have a limited understanding of how and why certain justifications become taken-for-granted reasons for an institution's existence.

In this article, we wish to add to the extant literature by arguing for a need to examine the structural properties of discursive institutional work undertaken to create, maintain, or disrupt the legitimacy of institutions in a more in-depth manner. More specifically, by drawing on contemporary philosophy (Brandom, 1994; Putnam, 1975; Sellars, 1956), we put forth the notion of "reasonability" as a perspective that helps to broaden our conceptions of rationality in institutional work. 
We connect reasonability to institutional work and elaborate on the "linguistic division of labour" (Putnam, 1975) in and around institutional work. Reasonability (or "discursive rationality"; see Habermas, 1986) relates to the simple observation that virtually every claim has a set of socially established criteria under which it is acceptable and a set of consequences it implies if accepted as true. As Wilfrid Sellars (1956) famously noted, our beliefs and claims reside in a space of reasons. Linguistic division of labor in turn explains that only some actors have the authority to maintain and at times develop the discursive basis that reasonability lies on.

\section{Reasonability in Institutional Work}

Institutions provide individuals with a sense of predictability and control by providing a shared order to the social world. It is widely acknowledged that the process takes place largely via discourse (Bourdieu, 1990; Foucault, 1994; Giddens, 1991). Through discourse, actors establish the appropriate ways of thinking and arguing. Accordingly, it is almost impossible to understand institutionalization in the absence of reasonability. Indeed, our interpretations are so dependent on some underlying reasons for actions and beliefs that accounts of irrationality typically rely on unconscious or unarticulated reasons (Davidson, 1982). Despite important advances in studies of institutional work, our understanding of this reflexive reasonability is still limited. This is at least partially because of the fact that analyses of discourse tend to emphasize its overwhelming power that operates at the subconscious level without paying attention to reflexive reasoning (Bourdieu, 1990; Foucault, 1995). Moreover, studies that have distinguished specific types of discursive legitimation in institutions (Suddaby \& Greenwood, 2005; Vaara \& Monin, 2010; Vaara \& Tienari, 2008) tend to define the process invery narrow terms, relying on immediately observable textual data. This has prevented researchers from fully grasping the central role of reasonability in institutional work, both in the sense of more or less purposeful legitimation of structures and practices as well as the perceived legitimacy of individual and organizational identities.

We argue that reasonability plays at least three crucial roles in institutional work: It provides the main contextual constraint of institutional work, its major outcome as well as the key trigger for actors to engage in. Reasonability simultaneously helps us to understand what discursive work is about and to trace the cultural and social structures that create, inhibit, and condition discursive work. Attention to discursive construction of reasonability provides a perspective to "the lived experience of organizational actors, and especially the connection between this lived experience and the institutions that structure and are structured by it" (Lawrence et al., 2011).

Reasonability as a constraint. Although recent institutional literature has examined the rhetoric and argumentation strategies of actors (Green, 2004; Green, Li, \& Nohria, 2009; Suddaby \& Greenwood, 2005), it has yet to examine the cognitive processes involved in reception of such rhetoric. Any claims put forth by actors need to be justifiable with acceptable reasons, must have some implications that recipients comprehend, and need to avoid clearly acceptable reasons for their refutation. This means that a fuller understanding 
of institutional work requires analyses that link specific rhetorical strategies to broader logics of reasoning and prevailingdiscourses through which abilities of arguments to stand as justifications are established.

Reasonability as an outcome. When actors engage in discursivework, they define and refine the generally accepted conditions for beliefs - the reasons why actors ought to believe one thing or another. They also shape the reasonable conclusions of beliefs or events by refining the implications of beliefs. For example, in writing about genetics, biologists and physicists (as well as journalists who popularize the writings) construct the way for us to reason about genes. This outcome is a key in the analysis of institutional work, and it is important to focus attention on the various ways in which specific rhetorical arguments, logics of reasoning, and discourses are linked to constitute the discursive bases of institutions. Also, future work in this area should take complexities, ambiguities, and contradictions seriously instead of assuming that the constructed systems of reasonability would be internally coherent or stable.

Reasonability as a trigger. Institutions appear legitimate only when actors are able to make sense of the reasons for and the consequences of their existence. For anyone to adopt total quality management or genetic tests, they must be able to reason their way around these topics. Crucially, new events and outcomes trigger sense making and require maintenance work for institutions to remain reasonable. The recent financial crisis could imply that existing global banking system were unsustainable were it not for skilful discursive work through which rationality of system was reestablished. Whether the crisis is a reason to change institutional arrangements depends on the way discursive reasonability gets reconstructed.

\section{The Linguistic Division of Labor}

It is also important to focus attention on the ways in which specific social actors are able to define, maintain, and control a particular space of reason. We know what genes are and that they can be measured to predict various individual outcomes. We also used to know that Pluto is a planet, although we now know that it is not (it is rather a class of celestial objects called "plutoids"). Although we are able to reason about genes and planets, our ability to use language for rational purposes relies on specialists. There are astronomers who take care of details related to planets, and biologists and physicians who take care of details related to genes. The institutional work around these concepts enables nonspecialist language users to employ them as tools in reasoning and communication. Words are powerful tools that depend on construction and maintenance work by powerful specialists. In talking or reasoning about genes, we hand significant power to specialists on whom we rely.

Hilary Putnam (1975), one of the most celebrated analytical philosophers of the previous century, has highlighted an important feature in the maintenance of the collective systems of meaning: the specialization in linguistic labor. Putnam challenged the notion that meanings reside within individuals, suggesting that meanings reside in linguistic 
communities with professionals charged for the maintenance of particular domains of meaning. His hypothesis is as follows:

"Every linguistic community exemplifies [linguistic] [ . . . ] division of labor [ . . ]: that is, possesses at least some terms whose associated "criteria" are known only to a subset of speakers who acquire the terms, and whose use by the other speakers depends upon a structured cooperation between them and the speakers in the relevant subsets."

(Putnam, 1975, p. 228)

Putnam (1975) used the division of linguistic labor to solve an inherent puzzle in theories of meaning: What are sufficient grounds to say that a speaker has grasped a concept. Most of us would claim to have sufficient command of the concept "gold," for instance. But do we really? Can we tell the difference between a golden object and a fake? Come to think of it, which of our everyday concepts are such that we would expect more or less any sane person to use reliably? Putnam's solution refers to linguistic communities, rather than individual language users. In situations where we are charged of determining whether something is gold, we rely on the expertise of experts within institutions charged with the maintenance of the meaning of gold, for example, metallurgists or goldsmiths. Reasonability is maintained by communities that exhibit division of linguistic labor.

This philosophical insight opens up a novel venue for empirical studies of institutional work. We know that professions hold authority over discursive domains (Scott, 2008), but very little is known about how these professions influence the broader community of language users. Reasonability requires multiple roles from professional specialists. The psychiatric profession, for instance, is responsible for the maintenance of a range of concepts, also used widely in popular discourse. As concepts such as "neurosis," "narcissism," "insanity," and "psychopath" quickly become stigmatized in popular discourse, the psychiatric profession needs to work constantly to repair and renew their concepts. In the financial world, it is possible to deal in "securitized mortgage instruments" without a full comprehension of their constitution because bankers hold control over the domain of language (and thus the domain of reasoning). The astronomical profession, after decades of maintaining the concept of Pluto as belonging to a privileged group of celestial objects (the group of planets in the solar system) had to react to new evidence that discounted this membership. After an extensive internal debate, they ended up creating a new category of celestial objects, plutoids, defining conditions for membership in this category.

This leads us to invite institutional scholars to pursue the following question:

Research Question 1: What are the roles of professionals and professional bodies in the maintenance of reasonability in an institutional domain?

The division of linguistic labor exists at various levels of analysis. In addition to societies, organizations and even groups within them delegate linguistic labor by relying on specific 
experts to maintain the meaning of particular terms. The HR department may be charged with the beliefs and practices that constitute the meaning of "change management," whereas the communications department owns and maintains the concept of "storytelling." In the media framing of nuclear accidents (Gamson \& Modigliani, 1989), the discursive maintenance work of institutionalized field of nuclear energy relies on experts who relate emerging facts (the accidents) with established beliefs (regarding the safety and reliability of nuclear power plants). Because the area of reasoning is under the control of specific social group (safety experts), the dominant frame depends on their institutional maintenance work. This suggests our second question:

Research Question 2: How do members of professions create and maintain spaces of reason within organizations and institutional fields?

Authority over spaces of reason provides professions with power over institutional domains. Only when things go wrong (reasonable predictability and control fails), the attention of outsiders — such as journalists - arises, challenging the profession into action. Strikingly, even governments cannot intervene in areas like health care or economy unless their actions are rational in the context of accepted "truths" of medical science or economics. The near-monopoly of professions in establishing discursive rationality provides them control over the range of possible new interventions and practices. This means that governments rely on economists to legitimize novel practices (that may or may not be invented by economists in the first place). The division of labor dictates who has the authority to evaluate, criticize, or change beliefs. Often division of linguistic labor creates power struggles, as the ability to control a domain of reasoning is a major source of power. This triggers our third question:

Research Question 3: What strategies do other actors use to engage with professions to shape the established spaces of reason?

Although attention has been focused on legitimacy established by institutional entrepreneurs, the literature thus far has largely ignored the spaces of reason that institutional entrepreneurs create around the formation of novel practices, structures, and ideas. Thus, the more fundamental question of authority over domains of knowledge has received scant attention. Foucault (1978) suggested that although expertise over sexuality was delegated to artists in Japan and many other countries, in Europe, the medical profession began to control the discourse of sexuality because of historical and social forces. In contemporary society, the expertise over emerging social areas, such as new occupations, professions, technological knowledge, and policy problems, gets distributed quite rapidly. Yet, we have little understanding on the social processes through which domains of expertise are claimed or delegated. This leads to our fourth question:

Research Question 4: What characterizes the institutionalization process where expertise over new meanings is determined and authority positions acquired and contested? 


\section{Conclusion}

In this article, we have drawn attention to reasonability and explored the novel venues of inquiry that the concepts of reasonability and the division of linguistic labor offer students of institutional work. Specifically, we suggest that the creation, maintenance, and disruption of institutions are inherently linked with spaces of reason, characterized by reasonability. "Institutional linguistic experts" in turn play a crucial role in establishing and maintaining reasonability across practices, events, characteristics, entities, norms, values, and so on. Such reasonability is a requirement for continued legitimacy (acceptability and comprehensibility) of institutionalized structures and practices. In contrast to some prevailing approaches (Berger \& Luckmann, 1967), the focus on reasonability assumes actors to reflect on the beliefs they hold, thus shifting the attention to the justifying reasons through which apparent rationality emerges.

Altogether, our brief comment encourages attention to sociology of knowledge in relation to institutional work. We believe that it is time to focus on the micro-level structural context of discursive institutional work. We believe reasonability is a fruitful perspective for this purpose. At the level of individual actors engaged in their everyday work, societal or field-level beliefs and demands meet with diverse experiences and practical challenges. What on macro level can appear to be coherent "institutional logics" or meaning structures (e.g., law, professional norms, economic theory) need to be accommodated with idiosyncratic complexities of particular situations. At such sites, the chosen high priests of a professional domain-designated by the discursive division of labor-apply their discursive authority to tasks at hand, establishing order, normality, and above all, the appearance of rationality. These processes need more attention if we want to better understand the nature of institutional work and its implications.

\section{Declaration of Conflicting Interests}

The author(s) declared no potential conflicts of interests with respect to the authorship and/or publication of this article.

\section{Funding}

The author(s) received no financial support for the research and/or authorship of this article. 


\section{References}

Berger, P. L., \& Luckmann, T. (1967). Social construction of reality: A treatise in the sociology of knowledge. New York, NY: Anchor Books.

Bourdieu, P. (1990). The logic of practice. Cambridge, UK: Polity Press.

Brandom, R. B. (1994). Making it explicit. Cambridge, MA: Harvard University Press.

Davidson, D. (1982). Paradoxes of irrationality. In R. Wollheim \& J. Hopkins (Eds.),

Philosophical essays on Freud (pp. 289-305). New York, NY: Cambridge University Press.

Foucault, M. (1978). History of sexuality, Volume 1. New York, NY: Pantheon Books.

Foucault, M. (1994). The birth of the clinic: An archeology of medical perception. New York, NY: Vintage Books.

Foucault, M. (1995). Discipline and punish: The birth of the prison. New York, NY:

Vintage Books.

Gamson, J., \& Modigliani, A. (1989). Media discourse and public opinion on nuclear power: A constructionist approach. American Journal of Sociology, 95, 1-37.

Giddens, A. (1991). Modernity and self-identity: Self and society in the late modern age. Stanford, CA: Stanford University Press.

Green, S. E. J. (2004). A rhetorical theory of diffusion. Academy of Management Review, 29, 653-669.

Green, S. E. J., Li, Y., \& Nohria, N. (2009). Suspended in self-spun webs of significance: A rhetorical model of institutionalization and institutionally embedded agency. Academy of Management Journal, 52, 11-36.

Habermas, J. (1986). The theory of communicative action. Cambridge, UK: Polity Press.

Hardy, C., \& Maguire, S. (2008). Institutional entrepreneurship. In C. O. R. Greenwood, K. Sahlin, \& R. Suddaby (Eds.), The Sage handbook of organizational institutionalism, (pp. 198-217). London, UK: SAGE.

Lawrence, T. B., Suddaby, R., \& Leca, B. (2009). Institutional work: Actors and agency in institutional studies of organizations. New York, NY: Cambridge University Press.

Lawrence, T., Suddaby, R., \& Leca, B. (2011). Institutional work: Refocusing institutional studies of organization. Journal of Management Inquiry, 20(1), 52-58.

Phillips, N., Lawrence, T. B., \& Hardy, C. (2004). Discourse and institutions. Academy of Management Review, 29, 635-652. 
Putnam, H. (1975). The meaning of “meaning.” In H. Putnam (Ed.), Mind, language, and reality: Philosophical papers (Vol. 2, pp. 215-271). Cambridge, UK: Cambridge University Press.

Scott, W. R. (2008). Lords of the dance: Professionals as institutional agents. Organization Studies, 29, 219-238.

Sellars, W. (1956). Empiricism and the philosophy of mind. In H. Feigl \& M. Scriven (Eds.), Minnesota studies in the philosophy of science, Volume I: The foundations of science and the concepts of psychology and psychoanalysis (pp. 253-329). Minneapolis: University of Minnesota Press.

Suddaby, R., \& Greenwood, R. (2005). Rhetorical strategies of legitimacy. Administrative Science Quarterly, 50, 35-67.

Vaara, E., \& Monin, P. (2010). A recursive perspective on discursive legitimation and organizational action in mergers and acquisitions. Organization Science, 21, 3-22.

Vaara, E., \& Tienari, J. (2008). A discursive perspective on legitimation strategies in multinational corporations. Academy of Management Review, 33, 985-993.

\section{Biographies}

Henri A. Schildt is an assistant professor of management and organization at Hanken School of Economics. His current interests focus on applying discursive perspectives to understand effects of institutional logics, the emergence of new organizational fields, and the formation of social categories. His prior research has focused on innovation and learning in technology related articles, with works published in Strategic Management Journal, Entrepreneurship Theory and Practice, and Strategic Organization.

Saku Mantere is a professor of management and organization at Hanken School of Economics. His research is focused on what makes organizations strategic and how strategic management affects organizations. He is particularly interested in strategic change, middle management agency, and strategy discourse.

Eero Vaara is a professor of management and organization at Hanken School of Economics in Helsinki, Finland, and a permanent visiting professor at EMLYON Business School, France. He is also the chair of European Group for Organizational Studies (EGOS). He received his PhD from Helsinki School of Economics. His research interests focus on strategy and strategizing, organizational change, multinational corporations and globalization, and methodological issues in management research. He has lately worked especially on discursive and narrative perspectives. 